\title{
Against All Odds: Survival of Traditional Javanese Food Stalls in the Municipality Of Malang, Indonesia
}

\author{
Astrida Fitri Nuryani ${ }^{1}$ \\ ${ }^{I}$ Department of Sociology, Brawijaya University, Indonesia.
}

\begin{abstract}
This paper would discuss about survival of traditional Javanese food stalls in the Municipality of Malang. The study was focused in the narratives of two old (ran for at least three generations) food stall owners in Malang. The two areas were counted among the municipality's culinary basis, and hence were selected purposively for the study. On the other hand, the stalls managed to survive despite the emergence of foreign fast food outlets around them, and thus were also selected for the study. The research approach in this study was qualitative approach, and the strategy was case study in the two abovementioned areas, with stall owners, and a neighborhood native as key informants, and other informants including a daughter of one of the owners, and three loyal customers of each food stall. The results showed that the stall owners, as well as their family members and loyal customers, contributed in the stalls's survival. Despite the many changes they must undergo in order to survive the foreign fast food chains emergence, they managed it because of embedded habitus and strong cultural as well as social capital.
\end{abstract}

Keywords: capitalism, habitus, cultural capital, food stalls, social capital

\section{Introduction}

Globalization initiated modernization in agriculture. Hence, changes happened in the chain of production, distribution and consumption that affected many. Changes in the stages of cultivation in the fields brought along changes in other aspects of farming, and with the latter, other changes in the stages of processing and distribution..

In Malang, a city with strong culinary culture since Colonial Dutch occupation era (Basundoro, 2009) early forms of food business were seen as early as the 19th century. However, beginning in the last decade, taste capitalism was detected in the growth of foreign fast food outlets, even in the neighborhoods with specific forms of communal interaction and close-knit food businesses (Nazaruddin, 2012). By offering attractive and continuously renewed products, fast service, clean and "modern"-styled premises, these outlets offered a different kind of eating experience from that at home or at traditional food stalls. In Malang alone, there are more than ten outlets of foreign fast food chains; one of them already has more than 100 outlets in Indonesia.

There was no previous research in Indonesia on survival of small businesses in capitalism, especially one that the actors's social role in and outside those businesses. Previous body of research on small business in globalization context was more focused in its general operational procedures. From the possibility of food dependence and the shaping of consumerism culture in Malang, this research was crucial. The research framed the phenomenon of capitalism from the survival of traditional Javanese food stalls, especially in relations with the people behind them; in this case the women who were involved in the traditional Javanese food business and their female customers.

Theoretically, this research attempted at providing an alternative interpretation on the theory of habitus and capital by Pierre Bourdieu. This theory puts a light on effects of social classes on members of those classes' taste. In Bourdieu's France, the upper classes always tried to impose their tastes to the lower classes, while the lower classes had always denounced this. Therefore, this research tried to see if something similar happens in Malang, and whether instead of dominance, the subordinate taste managed to survive.

\section{Theoretical Approach Of Bourdieu's Distinction And Habitus}

In Bourdieu's (1984) Distinction, he reveals that class and status are inseparable from social life. Therefore, the two concepts join together in a mutual assistance network, where culture and economy are linked. According to Bourdieu's postulation, there is an proportionally structural connection between the choice of lifestyle and social standing. According to Bourdieu, classes appear as status groups. Thus, tastes are culturally stratified, and economic domination helps to cement the stratification thereof. In this situation, members of dominant classes seem to be gifted instead of dominant. The structure of economic positions is thus misinterpreted symbols and lifestyles that are inherent in existing habitus.

Habitus is seen as an enduring systematical arrangements where its social context is related to the overall societal structure. Existence of each individual in a society is shaped by material exposure throughout 
their lives. Through socialization, members of different social classes are exposed to different materials related to their social conditions. which give rise to characteristic ways of perceiving and being in the world. The embedded habitus, therefore, is the origin of individual taste. There is a coalescing principle based on habitus regarding practices in different cultural fields. There are two types of capital in Bourdieu's concept, these are economic and cultural capital. When individuals have little capital, they must adjust with the dearth of materials that leads to economic consequences. With minimum capital, peasants and industrial workers as the lowest social class members are ceaselessly troubled with economic matters, and therefore contributes to the shaping of their acquired taste. For the lower class members, Bourdieu argues that the efforts to fulfill their necessity turn into parts of their taste that cause them to prefer things that are natural as well as functional instead of the artificial. The preference also signifies their abandonment of distinction. The dominant class is able to inflict its lifestyle on. However, their domination is not immediately visible. The dominant seems charismatic in the eyes of the lower class members, and the latter accept it. Thus, the former's power is continuously reproduced.

\section{Research Methods}

This study applied the case study strategy, and the analysis was based on Denscombe (2007). The study was located in two historical neighborhoods. Both areas were located in the sub district of $\underline{\mathrm{K}}$, Malang. Historically, the areas were one of the sites of local culinary culture in Malang. Earliest signs of traditional Javanese food business could be seen from as early as the $19^{\text {th }}$ century. Due to development, the sub disctrict evolved into a trade and business area, hence it was highly sought by business owners. There are several outlets surrounding the neighborhood were even located opposite to the two neighborhoods, in which there were traditional food stalls that had been maintained for at least three generations of family.The informants consist of an architect who is a neighborhood native as well as two traditional food stall owners with considerable knowledge of the neighborhood. One of the stalls were first established as early as the 1950s, and the other as early as 1970 s.

\section{Results And Discussion}

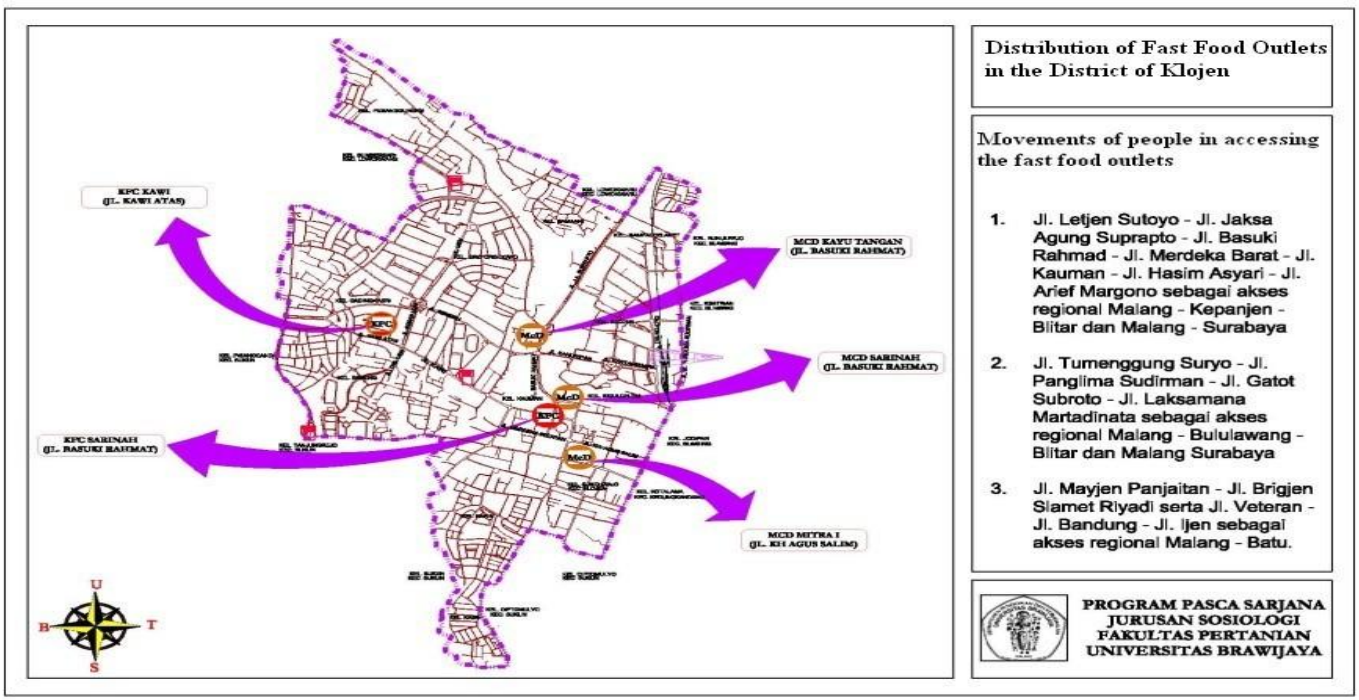

Figure 1. map of fast food outlet distribution

\subsection{Socialization Of Traditional Javanese Food}

Despite the emergence of foreign fast food chains in the subdistrict in general (as seen in Fig. 1), and in the two neighborhoods inside the subdistrict, traditional Javanese food stalls still survived in Malang, including in two historical neighborhoods. The two neighborhoods are historical, because they were amongst the first places where local food business were established during Dutch occupation era (Basundoro, 2009). Observations as regular customer, as well as interviews with stall owners, the customers preferred traditional Javanese food stalls because they were raised based on traditional family norms and values. Traditional street food as were explained by Hilmi and Fellows (2011) meant the food was prepared according to traditional recipes, with changes but not significant ones. For the customers of food stalls, this meant they had the sense of belonging in their families where they ate the traditionally cooked foods. These customers experienced periods of regular family mealtimes. In this context, family sitting at the dinner table together with all other family members. Usually, their mothers were meal providers and primary caregivers, while their fathers were breadwinners. Interview results also showed that the customers were introduced to the stalls by their parents. As 
children, the customers went to eat at the stalls together with their parents, for example on certain events that are considered special by the family. In observation of how families managing traditional Javanese food stalls, including how the members of these families interact with each other, it appears that family values were vital for their business to thrive. The formation of networks of interactions was also an important part of the stalls's survival. Not only that, but social capital was also formed by communal and familial shared norm and values, network, and reciprocity, which was different from Gould (2008)'s analysis.

\subsection{Habitus Of Traditional Food Stall Owners And Customers}

In other words, traditional food stalls habitus did not feel threatened by fast food, having formed the opinions of the difference in lifestyle, associated with the different tastes of the customers of foreign fast food outlets and theirs (the stalls's) customers. Differences in habitus also strengthened by taste-based social stratification in Malang, some of which were described through the case in this study, due to the embedded taste of the food stalls customers. Based on comparisons between traditional food stalls customer profile with customers of foreign fast-food outlets, which interviewed as informants in this study. Interviews showed that neither the customers nor the stall owners fully embraced the foreign food culture even though it had been almost a decade since a foreign fast food outlet was first established in Malang. In this research, it was evident that although the children of stall customers and owners alike were familiar with foreign fast food, they were still introduced to traditional foods and consumed the latter more than the former (fast food).

Food choice was one of the results of socialization. Hence, eating habits were among the first set of norms and values learned by the time a man consumed his first food. Research by Piscopo (2004) also mentions the family factor, school and television as influential, when determining food choice. Thus, family factors, for instance in this study, played a role in directing eating habits and taste of children in their family, and helped the children stay familiar with traditional food. Supporting the thesis of Clark (1998), Piscopo (2004), and Pietro (2008), analysis of interviews and observations showed the loyalty of the customers as a result of the efforts of the traditional food stall owners to maintain the quality of the food and drinks by staying true to the original recipes in spite of price fluctuation.

From observations and interviews with the stall owners and their customers, there seemed to be closeknit social relations between the stall owners and their customers. This situation, when juxtaposed with the relationship between the franchisor and the holder of the right franchise with its customers, generates a strongly different impression. A sense of shared fate also caused them to become lenient when customers could not readily pay for their meals. Networks also played a significant role in the form of mutual support in the event of urgent needs (when a family member is hospitalized, for example). The neighbors and customers joined to assist the stall owners. Thus the relations of this kind is a form of cultural capital in Bourdieu's concept, which cemented their relationship in the playing field, that might provide support for the lack of economic capital.

\section{Conclusions}

Traditional food stalls that has survived in this study is a family business with a pattern derived from the regeneration of habituation (habit formation) to the culture of the family business since childhood. Traditional food stall owners do not feel threatened by the presence of foreign fast food because they feel they are different market segments with foreign fast food outlets. In addition, they felt that the menu offered in the stores will not be accepted quickly by the community (not in a short time). Even so, the necessary attention to this sort of local businesses in order to expand its business in terms of hygiene, service or product, so that does not erode in the future.

For further research, it can be done a study on foreign capital in the city of Malang and the influence of foreign investors with bureaucratic cooperation in Malang, as well as the structure of capitalism in terms of the development of the working classes franchised fast food outlets.

\section{Acknowledgements}

I cannot express enough gratitude to my informants at the two neighborhoods, my supervisory committee, my classmates at the postgraduate program of Sociology at Brawijaya University, and my family.

\section{References}

[1]. P. Basundoro, Dua Kota Tiga Zaman: Surabaya dan Malang Sejak Kolonial Sampai Kemerdekaan. (Yogyakarta: Penerbit Ombak, 2009).

[2]. F. Nazaruddin, Pola pemanfaatan koridor jalan Kampung Kauman Kota sebagai ruang publik, master thesis.. Brawijaya University, Malang, Indonesia, 2012..

[3]. P. Bourdieu, 1984. Distinction: A Social Critique of The Judgment of Taste. (Cambridge, MA: Harvard University Press, 1984).

[4]. Denscombe, M. The good research guide: guide to small scale research. (New York, NY: McGraw-Hill, 2007).

[5]. Gould A. M. Working at McDonalds: some redeeming features of McJobs. Work Employment \& Society, (24), 780, 2010.

[6]. M. Hilmi, M \&. Fellows, P. 2011 Selling Street and Snack Foods. FAO Diversification Booklet 18. Rural Infrastructure and AgroIndustries Division. Rome: Food and Agriculture Organization of the United Nations. http://fao.org/docrep/015 
[7]. Piscopo, S. Socio-ecological factors influencing food choices and behaviours of Maltese primary schoolchildren, master thesis University of Birmingham, Birmingham, 2004.

[8]. Clark, J.E 1998, Taste and flavour: their importance in food choice and acceptance. Proceedings of the Nutrition Society (57), 639643

[9]. Pietro R. B. Retaining Hourly employees: Nebraska’s Quick Service Restaurant Industry Dilemma. (Nebraska: NebGuide of University of Nebraska, Nebraska, 2008) 